(C) 2017, THE AUTHORS. Published by FASS and Elsevier Inc. on behalf of the American Dairy Science Association ${ }^{\circledR}$.

This is an open access article under the CC BY-NC-ND license (http://creativecommons.org/licenses/by-nc-nd/3.0/).

\title{
Linear and nonlinear genetic relationships between type traits and productive life in US dairy goats
}

\author{
V. J. Castañeda-Bustos, ${ }^{*}$ H. H. Montaldo, ${ }^{* 1}$ M. Valencia-Posadas, $†$ L. Shepard, $\ddagger$ S. Pérez-Elizalde,§ \\ O. Hernández-Mendo,§ and G. Torres-Hernández§ \\ *Departamento de Genética y Bioestadística, Facultad de Medicina Veterinaria y Zootecnia, Universidad Nacional Autónoma de México, \\ Ciudad Universitaria, DF 04510, México \\ †División de Ciencias de la Vida, Campus Irapuato-Salamanca, Universidad de Guanajuato, Ex Hacienda El Copal, Irapuato, \\ Guanajuato 36500, México \\ $\ddagger$ American Dairy Goat Association, Spindale, NC 28160 \\ $\S$ Colegio de Postgraduados, Campus Montecillo, Montecillo, Estado de México 56230, México
}

\section{ABSTRACT}

Linear or nonlinear genetic relationships between productive life and functional productive life at $72 \mathrm{mo}$, with final score (SCO), stature, strength, dairyness (DAI), teat diameter, rear legs (side view), rump angle, rump width (RUW), fore udder attachment (FUA), rear udder height, rear udder arch, udder depth (UDD), suspensory ligament (SUS), and teat placement, as well as heritabilities and correlations were estimated from multibreed US dairy goat records. Productive life was defined as the total days in production until 72 mo of age (PL72) for goats having the opportunity to express the trait. Functional productive life (FPL72) was analyzed by incorporating first lactation milk yield, fat yield, protein yield, and SCO in the statistical model. Heritabilities and correlations were estimated using linear mixed models with pedigree additive genetic relationships and ASReml software. Nonlinearity of genetic relationships was assessed based on second-degree polynomial (quadratic) regression models, with the breeding values of PL72 or FPL72 as responses and the breeding values for each type trait (linear and quadratic) as predictor variables. Heritability estimates were $0.19,0.14,0.18,0.20,0.14,0.07,0.28,0.20,0.15,0.13$, $0.25,0.18,0.20,0.21,0.21$, and 0.32 for PL72, FPL72, SCO, stature, strength, DAI, teat diameter, rear legs, rump angle, RUW, FUA, rear udder height, rear udder arch, UDD, SUS, and teat placement, respectively. The type traits SCO, RUW, and FUA were the most correlated with PL72 and FPL72, so these may be used as selection criteria to increase longevity in dairy goats. An increase in the coefficient of determination $>1 \%$ for the second degree, compared with that for the linear model for either PL72 or FPL72, was taken as evidence

Received April 13, 2016.

Accepted September 28, 2016.

${ }^{1}$ Corresponding author: montaldo@unam.mx of a nonlinear genetic relationship. Using this criterion, PL72 showed maximum values at intermediate scores in DAI, UDD, and RUW, and maximum values at extreme scores in FUA and SUS, whereas FPL72 showed maximum values at intermediate scores in DAI and UDD, and maximum values at extreme scores in FUA, RUW, and SUS. Selecting for increased SCO, RUW, and FUA will lead to an increase of FPL72 in goats. Consideration of nonlinear relationships between DAI, FUA, RUW, SUS, and UDD may help in the design of more efficient breeding programs for dairy goats using conformation traits.

Key words: productive life, type traits, heritability, genetic correlation, nonlinear relationship

\section{INTRODUCTION}

Productive life in dairy goats has been defined as total days in production (Castañeda-Bustos et al., 2014) or as stayability (Valencia-Posadas et al., 2010; PérezRazo et al., 2004). Milk production, reproduction, and health traits are among the factors that determine the longevity of an animal in a dairy herd (Rogers et al., 1998; Jensen et al., 1999; Sewalem et al., 2008). Longevity values are determined by both voluntary and involuntary culling. Functional productive life, which is defined as the ability to avoid involuntary culling (Mark, 2004), has been estimated by including firstlactation milk, fat yield, protein yield, and final type score as covariates in statistical models for the genetic evaluation of longevity, to correct for the influence of voluntary culling (Castañeda-Bustos et al., 2014). Nonetheless, the differences between the genetic parameters of productive life and functional productive life have been relatively small in goats (Castañeda-Bustos et al., 2014).

Although longevity is an economically important trait in all domestic species (Tarrés et al., 2006; du Toit et al., 2009; Mekkawy et al., 2009) insofar as it 
can increase the average herd life as well as reduce the replacement rate (Tsuruta et al., 2005; Sewalem et al., 2007), it has been studied little and to date is not used in the selection of goats. Direct selection for longevity is not feasible because the animal must die before its value for the trait is known. Although it is true that an animal's own information is not complete at the time that breeding decisions must be made, an evaluation using relatives can provide useful information.

In this situation, value exists in using traits genetically correlated with longevity that may be measured at a younger age to select animals with greater functional productive life. In a previous study, various traits, such as milk yield, fat yield, protein yield, combined fat and protein yield, fat percentage, protein percentage, age at first kidding, and interval between the first and second kidding, were evaluated as indirect selection criteria to increase productive life in goats (Castañeda-Bustos et al., 2014). Their study considered that the genetic trend for productive life at 72 mo could increase up to $38.3 \%$ per generation (with respect to direct selection) when one of the type traits studied was used as a selection criterion. In addition, available data on milk-producing cattle (Forabosco, 2005; Tsuruta et al., 2005; Samoré et al., 2010), swine (Tarrés et al., 2006), and sheep (Mekkawy et al., 2009) indicates that some type traits could be used for the genetic evaluation of longevity in goats.

In the United States, genetic evaluations have been performed annually for type traits in dairy goats since 1986 for final type score, and since 1989 to for 13 additional linear type traits (Wiggans and Hubbard, 2001), including stature, strength, dairyness, teat diameter, rear legs (side view), angle rump, rump width, fore udder attachment, rear udder height, rear udder arch, udder depth, suspensory ligament, and teat placement (Shepard, 2009). The linear appraisal system of the American Dairy Goat Association for type traits evaluates each trait from one observed biological extreme to the other, assigning a score or rating that ranges from 1 to 50 points, whereas the final type score is assessed as 50 to 99 points based on the importance given to each of the structural categories, which are general appearance $(35 \%)$, dairy character $(20 \%)$, body capacity (10\%), and mammary system (35\%; ADGA, 2012).

The relation between longevity and type traits has been studied extensively in cattle, finding genetic correlations between type traits and longevity of -0.19 to 0.48 (Vollema and Groen, 1997; Tsuruta et al., 2005 ) and -0.34 to 0.74 with stayability (Vollema and Groen, 1997; Valencia et al., 2008), but this has not been studied in goats. In the case of type traits it is not enough to know the genetic correlations these may have with longevity, as in some studies (e.g., Dekkers and Gibson, 1998; Larroque and Ducrocq, 2001; Zavadilová and Štipková, 2012) it has been observed that the relationship between longevity and type traits is not always linear, and a desirable optimum may be found at intermediate scores (Foster et al., 1989; Dekkers and Gibson, 1998; Zavadilová and Štipková, 2012). Their findings indicate that this type of study should consider the existence of nonlinear genetic relationships. Nonlinear relationships could be found in goats, as the conformation appraisal system assigns ratings on a quantitative scale based on the biological range of each trait (i.e., from one extreme of the physical trait to the other; Shepard, 2009). Thus, the objective of the current study was to examine the genetic relationships, both linear and nonlinear, between type traits and productive life and functional productive life at $72 \mathrm{mo}$ in dairy goats in the United States, as well as to estimate the heritabilities of these traits.

\section{MATERIALS AND METHODS}

\section{Data}

Records of goats from the Alpine, La Mancha, Nubian, Saanen, and Toggenburg breeds were used for milk production traits, standardized to 305-d and mature equivalents (Wiggans and Dickinson, 1985), and type traits (ADGA, 2012), adjusted for age at the time of the appraisal (Wiggans, 2006), obtained by the American Dairy Goat Association for the period from 1988 to 2005. The file contained data on first-lactation records for milk yield (MIY), fat yield (FAY) and protein yield (PRY), date of appraisal, final score (SCO), which allows for an appraisal of the general conformation of the animal, and 13 linear traits: stature (STA), strength (STR), dairyness (DAI), teat diameter (TED), rear legs (side view; REL), rump angle (RUA), rump width (RUW), fore udder attachment (FUA), rear udder height (RUH), rear udder arch (RUC), udder depth (UDD), suspensory ligament (SUS), and teat placement (TPS). Type records were adjusted for the age of the doe at appraisal (adjustment factors available at https://www.cdcb.us/reference/goat/goat.type.age. html). Linear traits or SCO with scores outside limits established by ADGA (2012) were set as missing. If a doe had more than 1 conformation score, only the first of these was considered in our study.

The final edited data set used in the analysis contained production data (MIY, FAY, and PRY) and conformation scores for 14 traits of 12,626 daughters of 3,077 sires and 5,940 dams. Data of individuals lacking information on breed, identification, or birth date were eliminated from the original pedigree data set. The pedigree was subsequently ordered generationally and recoded using Pedigree Viewer 6.3 software (Kinghorn 
and Kinghorn, 2009); the final file contained complete information on 46,564 individuals, including ancestors without information for conformation traits.

The age of the animals was calculated as the difference between the last date of kidding and date of birth plus the last days in production recorded, subsequently calculating productive life at 72 mo (PL72), defined as the total number of days in production recorded until the doe was 72 mo of age. This was used as a measure of the length of the useful life of the goat (CastañedaBustos et al., 2014).

To obtain the PL72, it was first determined whether, based on the testing dates of the herd to which it belonged, the goat had the opportunity to remain in the herd up to $72 \mathrm{mo}$ as follows: last herd testing date available minus date of birth. If the difference was $\geq 72$ mo, the goat had the opportunity to stay in the herd.

If the goat had the opportunity to stay in the herd, its PL72 was the sum of the days of milk production recorded (with a maximum of $305 \mathrm{~d}$ per lactation) up to $72 \mathrm{mo}$ of age. If the goat did not have the opportunity to stay in the herd (difference between dates $<72$ mo), the PL72 was considered a missing value and was not included in the final file for analysis. The final file includes records of goats with productions from 1 to 10 lactations. To avoid abnormal records related to management problems or nonproductive herds, PL72 values lower than 100 were not included in the final data set. It should be emphasized that a PL72 record for a given goat does not imply that this goat was kept to the age of $72 \mathrm{mo}$, but merely that the goat had the opportunity to reach 72 mo of production.

In this study we analyzed 16 traits: SCO, STA, STR, DAI, TED, REL, RUA, RUW, FUA, RUH, RUC, UDD, SUS, TPS, PL72, and functional productive life at 72 mo (FPL72).

\section{Statistical Models}

Four birth seasons (BS)-March, April, May to July, and August to February - were defined to balance the number of observations across seasons, given that, due to the reproductive seasonality of this species, births were concentrated in certain months of the year. Subsequently, BS was combined with the breed (Alpine, La Mancha, Nubian, Saanen, and Toggenburg) and 20 levels of birth season-breed (BSB) were obtained.

Variables were analyzed using a univariate animal model to estimate the phenotypic, additive genetic, and residual variances, using restricted maximum likelihood with ASReml 3.0 software (Gilmour et al., 2009). The model used for PL72, expressed in matrix notation (Mrode, 2005), was as follows:

$$
\mathbf{y}=\mathbf{X b}+\mathbf{Z u}+\mathbf{e},
$$

where $\mathbf{y}$ is the vector of observations for PL72; $\mathbf{X}$ is the incidence matrix of BSB; $\mathbf{b}$ is the vector of fixed effects of BSB; $\mathbf{Z}=\left[\begin{array}{ll}\mathbf{Z}_{1} & \mathbf{Z}_{2} \\ \mathbf{Z}_{3}\end{array}\right]$ is the incidence matrix of additive genetic effects of the animal $\left(\mathbf{Z}_{1}\right)$, herd-year of birth-breed $\left(\mathbf{H Y B} ; \mathbf{Z}_{2}\right)$ and herd-sire effect $\left(\mathbf{H S} ; \mathbf{Z}_{\mathbf{3}}\right)$; $\mathbf{u}^{\prime}=\left[\begin{array}{lll}\mathbf{u}_{1}^{\prime} & \mathbf{u}_{2}^{\prime} & \mathbf{u}_{3}^{\prime}\end{array}\right]$ is the vector of random effects of the additive genetic effects of the animal $\left(\mathbf{u}_{1}\right)$, HYB $\left(\mathbf{u}_{2}\right)$, and HS $\left(\mathbf{u}_{3}\right)$; and $\mathbf{e}$ is the vector of random error.

The model used for each type trait, expressed in matrix notation (Mrode, 2005), was as follows:

$$
\mathbf{y}=\mathbf{X b}+\mathbf{Z u}+\mathbf{e},
$$

where $\mathbf{y}$ is the vector of observations for each type trait; $\mathbf{X}$ is the incidence matrix of breed-month of appraisal; $\mathbf{b}$ is the vector of fixed effects of breed-month of appraisal; $\mathbf{Z}=\left[\mathbf{Z}_{1} \mathbf{Z}_{2} \mathbf{Z}_{3}\right]$ is the incidence matrix of additive genetic effects of the animal $\left(\mathbf{Z}_{1}\right)$, herd-month of appraisal-breed (HMB; $\mathbf{Z}_{\mathbf{2}}$ ) and herd-sire effect (HS; $\left.\mathbf{Z}_{3}\right) ; \mathbf{u}^{\prime}=\left[\begin{array}{lll}\mathbf{u}_{1}^{\prime} & \mathbf{u}_{2}^{\prime} & \mathbf{u}_{3}^{\prime}\end{array}\right]$ is the vector of random effects of the additive genetic effects of the of the animal $\left(\mathbf{u}_{1}\right)$, $\operatorname{HMB}\left(\mathbf{u}_{2}\right)$, and HS $\left(\mathbf{u}_{3}\right)$; and $\mathbf{e}$ is the vector of random error.

Model assumptions were

$$
\begin{aligned}
& \operatorname{var}\left[\begin{array}{l}
\mathbf{u} \\
\mathbf{e}
\end{array}\right]=\operatorname{var}\left[\begin{array}{l}
\mathbf{u}_{\mathbf{1}} \\
\mathbf{u}_{2} \\
\mathbf{u}_{\mathbf{3}} \\
\mathbf{e}
\end{array}\right]= \\
& {\left[\begin{array}{cccc}
\mathbf{A} \sigma_{a}^{2} & 0 & 0 & 0 \\
0 & \mathbf{I} \sigma_{\mathrm{HB}}^{2} & 0 & 0 \\
0 & 0 & \mathbf{I} \sigma_{\mathrm{HS}}^{2} & 0 \\
0 & 0 & 0 & \mathbf{I} \sigma_{e}^{2}
\end{array}\right] \text { (Schaeffer, 2004), }}
\end{aligned}
$$

assuming normal density $(\sim N)$ for $\mathbf{y}, \mathbf{e}$, and $\mathbf{u}$,

$$
\begin{gathered}
y \sim N\left(\mathbf{X} \boldsymbol{\beta}, \mathbf{Z G} \mathbf{Z}^{\prime}+\mathbf{R}\right), \\
\mathbf{e} \sim N(0, \mathbf{R}), \text { and } \\
\mathbf{u} \sim N(0, \mathbf{G}) \quad \text { Searle, 1987); }
\end{gathered}
$$

where $\mathbf{X}$ is the incidence matrix for fixed effects, $\boldsymbol{\beta}$ is the vector of fixed effects, $\mathbf{R}=\mathbf{I} \sigma_{e}^{2}$ is the residual covariance matrix, $\mathbf{I}$ is an identity matrix; 
$\mathbf{G}=\left[\begin{array}{ccc}\mathbf{A} \sigma_{a}^{2} & 0 & 0 \\ 0 & \mathbf{I} \sigma_{H B}^{2} & 0 \\ 0 & 0 & \mathbf{I} \sigma_{H S}^{2}\end{array}\right], \quad$ is the variance-covariance matrix for random effects, $\mathbf{A}$ is the additive genetic relationship matrix; $\sigma_{a}^{2}, \sigma_{H B}^{2}$, and $\sigma_{H S}^{2}$ are the direct additive genetic variance, variance due to HYB or HMB effects, and the variance due to HS effect, respectively (Schaeffer, 2004). Note that the covariances between vectors $\left(\mathbf{u}_{1}\right),\left(\mathbf{u}_{2}\right)$, and $\left(\mathbf{u}_{3}\right)$ were null.

Contemporary effects, such as HYB and HMB, are often considered fixed, but research demonstrates the statistical advantages of considering contemporary group effects as random rather than fixed, especially when the number of observations by level is small (Schaeffer, 2009). To avoid loss of information and to reduce the possibility of bias in obtaining the variance components (Chauhan, 1987; Van Bebber et al., 1997), HYB and HMB were considered random in the current study. Convergence of the analyses was assumed when the change in the restricted likelihood function was less than 0.002 and the change in the parameter estimates was less than 1\% (Gilmour et al., 2009).

The model used for the estimation of genetic parameters for type traits (SCO, STA, STR, DAI, TED, REL, RUA, RUW, FUA, RUH, RUC, UDD, SUS, and TPS) included HMB as a random effect, whereas for longevity traits (PL72 and FPL72) the random effect considered was HYB. The random effect of HS was included in the model for all variables analyzed. The MIY, FAY, PRY, and SCO traits were included in the model as covariates for the analysis of FPL72 (Castañeda-Bustos et al., 2014). These covariates were not included in the model for the analysis of PL72.

\section{Genetic Parameters}

Components of variance and heritability were obtained using univariate animal models (Mrode, 2005).

Heritability. To calculate heritability within herdbreed, total variance and phenotypic variance were estimated as follows. Total variance:

$$
\hat{\sigma}_{t}^{2}=\hat{\sigma}_{a}^{2}+\hat{\sigma}_{\mathrm{HB}}^{2}+\hat{\sigma}_{\mathrm{HS}}^{2}+\hat{\sigma}_{e}^{2},
$$

where $\hat{\sigma}_{t}^{2}$ is the total estimated variance; $\hat{\sigma}_{a}^{2}$ is the estimated additive genetic variance of the animal; $\hat{\sigma}_{\mathrm{HB}}^{2}$ is the estimated HMB or HYB variance, according to the trait studied; $\hat{\sigma}_{\mathrm{HS}}^{2}$ is the estimated variance of the $\mathrm{HS}$ effect; and $\hat{\sigma}_{e}^{2}$ is the estimated error variance.

Phenotypic variance:

$$
\hat{\sigma}_{p}^{2}=\hat{\sigma}_{a}^{2}+\hat{\sigma}_{\mathrm{HS}}^{2}+\hat{\sigma}_{e}^{2},
$$

where $\hat{\sigma}_{p}^{2}$ is estimated phenotypic variance.

Once the total and phenotypic variances were obtained, heritability $\left(\hat{h}^{2}\right)$ was estimated by

$$
\hat{h}^{2}=\frac{\hat{\sigma}_{a}^{2}}{\hat{\sigma}_{p}^{2}} .
$$

Contribution of $H Y B$ and $H S$ Effects. To determine the contribution of HYB and HS effects in the $\hat{\sigma}_{t}^{2}$, the herd-year-breed ratio (HYBR) was calculated as

$$
\mathrm{HYBR}=\frac{\hat{\sigma}_{\mathrm{HB}}^{2}}{\hat{\sigma}_{t}^{2}},
$$

And the herd-sire ratio (HSR):

$$
\mathrm{HSR}=\frac{\hat{\sigma}_{\mathrm{HS}}^{2}}{\hat{\sigma}_{t}^{2}} .
$$

Variances obtained from a univariate animal model were used to estimate both HSR and HYBR.

Genetic and Phenotypic Correlations. Genetic $\left(\mathbf{r}_{\mathrm{g}}\right)$ and phenotypic $\left(\mathbf{r}_{\mathrm{p}}\right)$ correlations were obtained using bivariate animal models (Mrode, 2005), which included the same effects included in the univariate models mentioned above. Analyses were performed using ASReml 3.0 software (Gilmour et al., 2009). To test whether $r_{g}$ and $r_{p}$ were different from zero, $95 \%$ significance level confidence intervals were estimated using the psychometrics package for R (Fletcher, 2010).

\section{Nonlinear Genetic Relationships}

Nonlinear genetic additive relationships between PL72 and FPL72 with each type trait were determined using the second-degree polynomial approach developed by Fuerst-Waltl et al. (1998). We first estimated all additive genetic variances and covariances between PL72 (FPL72), each type trait, and each type trait squared. Models used for these analyses were similar to models previously described used to estimate genetic parameters for PL72, FPL72, and type traits; however, HS effects were not included in these models to ensure convergence. The analyzed data set consisted of records $(\mathrm{n}=6,136)$ without missing observations for all traits and effects included in all the analyses.

Estimated genetic additive (co)variances and number of observations were then used to set up normal 
least-squares equations (matrices of sum of squares and products for previously mentioned variables), and to solve them to obtain the regression coefficients (Draper and Smith, 2014). The importance of nonlinear relationships was evaluated from the difference between the coefficient of adjusted coefficient of determination $\left(\mathrm{R}^{2} \mathrm{adj}\right)$ of the second degree polynomial model, compared with that for the first degree (linear) model (Draper and Smith, 2014).

$$
\mathrm{R}^{2} \operatorname{adj}=1-\left[\left(1-\mathrm{R}^{2}\right) \mathrm{N} /(\mathrm{N}-\mathrm{k})\right]
$$

where $\mathrm{k}=$ degrees of freedom of the model, $\mathrm{N}=$ total sample size, and $\mathrm{R}^{2}=$ sum of squares of regression/ total sum of squares.

Statistical significance for linear and quadratic regression coefficients was obtained using $t$-tests involving the ratio of the estimate and standard error. For type traits with increases in $\mathrm{R}^{2}$ adj $\geq 1 \%$ in the second-degree model for either PL72 or FPL72, a plot of predicted PL72 and FPL72 versus the type trait was obtained. Each curve was adjusted to have a minimum value of zero in the observed interval and was expressed in phenotypic standard deviation units of either PL72 or FPL72.

\section{RESULTS}

The correlation coefficient between lactation number and PL72 in our data set was 0.96. Descriptive statistics for the traits evaluated are in Table 1.

\section{Genetic Parameters}

Variances (total, phenotypic, and additive genetic), HYBR, HSR, and heritabilities for the traits evaluated are in Table 2. Heritability estimates for PL72 and FPL72 were $0.19 \pm 0.01$ and $0.14 \pm 0.01$, respectively. Heritability estimates for conformation traits ranged from 0.07 to $0.32(\mathrm{SE}=0.02)$ in all cases; DAI and TPS were the traits with the lowest and highest heritability estimate, respectively. The values of HYBR and HSR for type traits ranged from 0.19 to 0.34 and 0.05 to 0.17 , respectively.

\section{Genetic and Phenotypic Correlations}

The majority of the $r_{g}$ and $r_{p}$ between type traits and PL72 and FPL72 (Table 3) were found to be significant $(P<0.05)$. The type traits SCO, FUA, and RUW were the most genetically related to PL72 $(0.52,0.34$, and 0.29 , respectively) and FPL72 (0.52, 0.34, and 0.22, respectively). Type traits least related to PL72 were STR $\left(r_{\mathrm{g}}=-0.01\right)$, REL $\left(\mathrm{r}_{\mathrm{g}}=0.01\right)$, and TED $\left(\mathrm{r}_{\mathrm{g}}=\right.$ $-0.04)$; least related to FPL72 were SUS $\left(r_{g}=0.02\right)$ and RUA $\left(\mathrm{r}_{\mathrm{g}}=-0.04\right)$, respectively.

The highest estimated $r_{p}$ were between PL72 or FPL72 and SCO (0.25 and 0.22, respectively) and the lowest $r_{p}$ were between TPS and PL72 $(-0.004)$ or FPL72 (0.008). The trait that displayed the greatest $r_{g}$ and $r_{p}$ with PL72 and FPL72 was SCO, making it the trait most genetically and phenotypically related to the PL72 of goats.

\section{Nonlinear Genetic Relationships}

Increases in $\mathrm{R}^{2}$ adj obtained using a second-degree polynomial model, compared with a linear model, were less than $1 \%$ for most type variables for both PL72 and FPL72 (Table 4). This occurred despite the fact that quadratic regression coefficients were significant for most type traits for PL72, and slightly less so for

Table 1. Descriptive statistics for the traits ${ }^{1}$ analyzed in dairy goats

\begin{tabular}{|c|c|c|c|c|c|c|c|}
\hline Trait & Abbreviation & $\mathrm{n}$ & Mean & $\mathrm{SD}$ & Minimum & Maximum & $\mathrm{CV}(\%)$ \\
\hline Productive life at 72 mo (d) & PL72 & 21,811 & 625.78 & 451.88 & 100 & 2,997 & 72.21 \\
\hline Final score (score) & $\mathrm{SCO}$ & 12,626 & 83.79 & 4.11 & 58.18 & 95.11 & 4.95 \\
\hline Stature (score) & STA & 12,626 & 27.57 & 8.97 & 1.04 & 49.68 & 32.55 \\
\hline Strength (score) & STR & 12,626 & 28.70 & 4.56 & 6.65 & 49.38 & 15.89 \\
\hline Dairyness (score) & DAI & 12,626 & 32.83 & 4.17 & 4.98 & 48.77 & 12.70 \\
\hline Teat diameter (score) & TED & 12,626 & 23.00 & 6.93 & 2.65 & 49.11 & 30.13 \\
\hline Rear legs (side view) (score) & REL & 12,626 & 26.74 & 3.54 & 5.10 & 43.29 & 13.26 \\
\hline Rump angle (score) & RUA & 12,626 & 31.40 & 6.34 & 4.60 & 49.96 & 20.20 \\
\hline Rump width (score) & RUW & 12,626 & 27.01 & 4.53 & 2.10 & 49.51 & 16.78 \\
\hline Fore udder attachment (score) & FUA & 12,626 & 31.57 & 4.88 & 3.15 & 49.69 & 15.47 \\
\hline Rear udder height (score) & RUH & 12,626 & 34.76 & 6.17 & 3.01 & 49.95 & 17.74 \\
\hline Rear udder arch (score) & RUC & 12,626 & 22.43 & 6.32 & 1.93 & 47.41 & 28.17 \\
\hline Udder depth (score) & UDD & 12,626 & 31.45 & 5.90 & 2.29 & 49.89 & 18.75 \\
\hline Suspensory ligament (score) & SUS & 12,626 & 27.07 & 5.39 & 2.02 & 49.49 & 19.94 \\
\hline Teat placement (score) & TPS & 12,626 & 18.08 & 8.22 & 1.00 & 49.79 & 45.45 \\
\hline
\end{tabular}

${ }^{1}$ Type traits scores adjusted for age of doe at kidding; $\mathrm{n}=$ number of observations. 


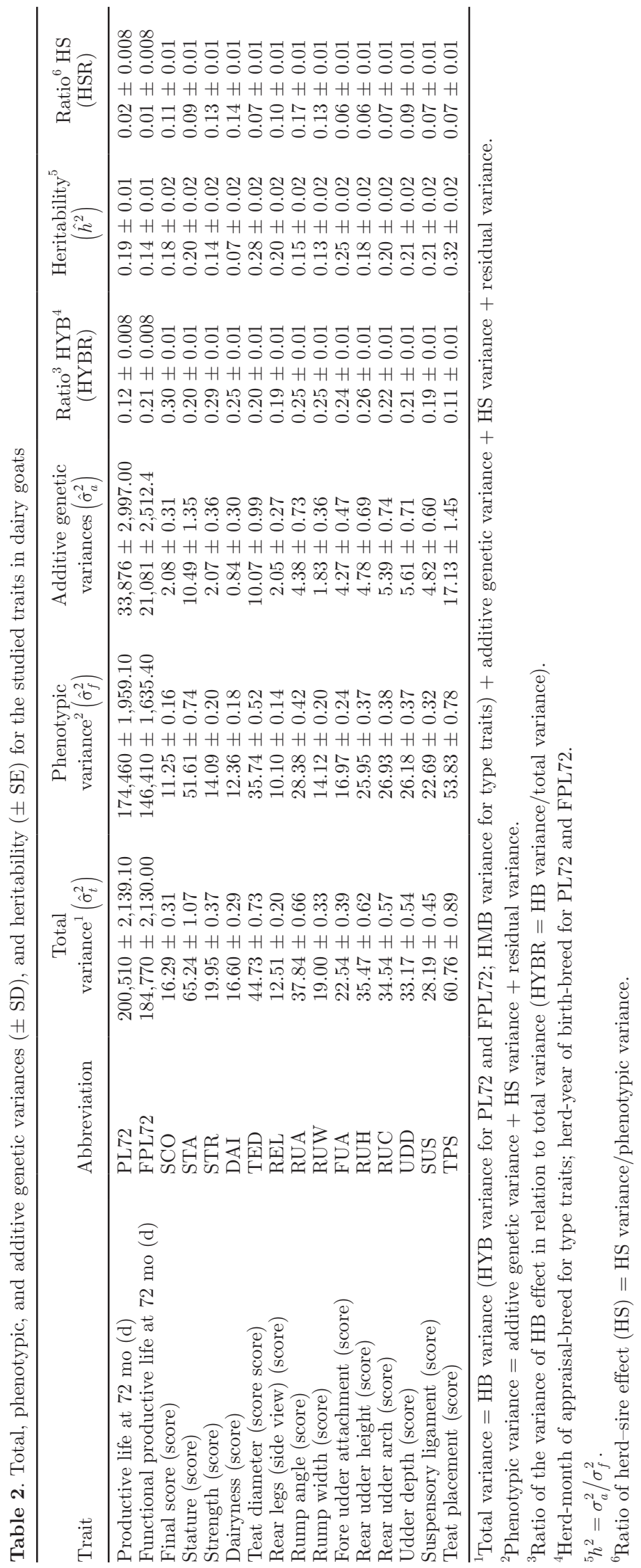


Table 3. Genetic and phenotypic correlations $( \pm \mathrm{SE})$ and their confidence intervals ${ }^{1}$ between type traits and productive life and functional productive life at 72 mo in dairy goats

\begin{tabular}{|c|c|c|c|c|c|}
\hline \multirow[b]{2}{*}{ Trait } & \multirow[b]{2}{*}{ Abbreviation } & \multicolumn{2}{|c|}{ Genetic correlation } & \multicolumn{2}{|c|}{ Phenotypic correlation } \\
\hline & & $\begin{array}{c}\text { Productive } \\
\text { life at } \\
72 \text { mo (PL72) }\end{array}$ & $\begin{array}{c}\text { Functional } \\
\text { productive life } \\
\text { at } 72 \text { mo (FPL72) }\end{array}$ & $\begin{array}{c}\text { Productive } \\
\text { life at } \\
72 \text { mo (PL72) }\end{array}$ & $\begin{array}{c}\text { Functional } \\
\text { productive life } \\
\text { at } 72 \text { mo (FPL72) }\end{array}$ \\
\hline Final score & $\mathrm{SCO}$ & $\begin{array}{l}0.52 \pm 0.09 \\
\quad(0.50 \text { to } 0.53)\end{array}$ & $\begin{array}{l}0.52 \pm 0.11 \\
\quad(0.50 \text { to } 0.53)\end{array}$ & $\begin{array}{l}0.25 \pm 0.01 \\
\quad(0.23 \text { to } 0.26)\end{array}$ & $\begin{array}{l}0.22 \pm 0.01 \\
\quad(0.20 \text { to } 0.23)\end{array}$ \\
\hline Stature & STA & $\begin{array}{l}0.21 \pm 0.09 \\
\quad(0.19 \text { to } 0.22)\end{array}$ & $\begin{array}{l}0.16 \pm 0.10 \\
\quad(0.14 \text { to } 0.17)\end{array}$ & $\begin{array}{l}-0.02 \pm 0.01 \\
\quad(-0.03 \text { to }-0.002)\end{array}$ & $\begin{array}{l}-0.03 \pm 0.01 \\
\quad(-0.04 \text { to }-0.01)\end{array}$ \\
\hline Dairyness & DAI & $\begin{array}{l}0.18 \pm 0.14 \\
(0.16 \text { to } 0.19)\end{array}$ & $\begin{array}{l}0.21 \pm 0.17 \\
(0.19 \text { to } 0.22)\end{array}$ & $\begin{array}{l}0.03 \pm 0.01 \\
\quad(0.01 \text { to } 0.04)\end{array}$ & $\begin{array}{l}0.01 \pm 0.01 \\
(-0.007 \text { to } 0.02)\end{array}$ \\
\hline Teat diameter & TED & $\begin{array}{l}-0.04 \pm 0.07 \\
\quad(-0.05 \text { to }-0.02)\end{array}$ & $\begin{array}{l}-0.08 \pm 0.09 \\
\quad(-0.09 \text { to }-0.06)\end{array}$ & $\begin{array}{l}-0.02 \pm 0.01 \\
\quad(-0.03 \text { to }-0.002)\end{array}$ & $\begin{array}{l}-0.03 \pm 0.01 \\
\quad(-0.04 \text { to }-0.01)\end{array}$ \\
\hline Rear legs (side view) & REL & $\begin{array}{l}0.01 \pm 0.08 \\
(-0.007 \text { to } 0.02)\end{array}$ & $\begin{array}{l}0.09 \pm 0.10 \\
\quad(0.07 \text { to } 0.10)\end{array}$ & $\begin{array}{l}0.01 \pm 0.01 \\
(-0.007 \text { to } 0.02)\end{array}$ & $\begin{array}{l}0.02 \pm 0.01 \\
\quad(0.002 \text { to } 0.03)\end{array}$ \\
\hline Rear udder height & $\mathrm{RUH}$ & $\begin{array}{l}0.19 \pm 0.09 \\
\quad(0.17 \text { to } 0.20)\end{array}$ & $\begin{array}{l}0.09 \pm 0.10 \\
\quad(0.07 \text { to } 0.10)\end{array}$ & $\begin{array}{l}0.11 \pm 0.01 \\
\quad(0.09 \text { to } 0.12)\end{array}$ & $\begin{array}{l}0.09 \pm 0.01 \\
\quad(0.07 \text { to } 0.10)\end{array}$ \\
\hline Rear udder arch & RUC & $\begin{array}{l}0.17 \pm 0.08 \\
\quad(0.15 \text { to } 0.18)\end{array}$ & $\begin{array}{l}0.15 \pm 0.10 \\
\quad(0.13 \text { to } 0.16)\end{array}$ & $\begin{array}{l}0.08 \pm 0.01 \\
\quad(0.06 \text { to } 0.09)\end{array}$ & $\begin{array}{l}0.08 \pm 0.01 \\
\quad(0.06 \text { to } 0.09)\end{array}$ \\
\hline Udder depth & UDD & $\begin{array}{l}0.17 \pm 0.08 \\
\quad(0.15 \text { to } 0.18)\end{array}$ & $\begin{array}{l}0.36 \pm 0.10 \\
\quad(0.34 \text { to } 0.37)\end{array}$ & $\begin{array}{l}-0.06 \pm 0.01 \\
\quad(-0.07 \text { to }-0.04)\end{array}$ & $\begin{array}{l}0.005 \pm 0.01 \\
\quad(-0.01 \text { to } 0.02)\end{array}$ \\
\hline Suspensory ligament & SUS & $\begin{array}{l}0.04 \pm 0.08 \\
\quad(0.02 \text { to } 0.05)\end{array}$ & $\begin{array}{l}0.02 \pm 0.10 \\
\quad(0.002 \text { to } 0.03)\end{array}$ & $\begin{array}{l}-0.02 \pm 0.01 \\
\quad(-0.03 \text { to } 0.002)\end{array}$ & $\begin{array}{l}-0.04 \pm 0.01 \\
\quad(-0.05 \text { to }-0.02)\end{array}$ \\
\hline Teat placement & TPS & $\begin{array}{l}0.06 \pm 0.07 \\
\quad(0.04 \text { to } 0.07)\end{array}$ & $\begin{array}{l}0.12 \pm 0.08 \\
\quad(0.10 \text { to } 0.13)\end{array}$ & $\begin{array}{l}-0.004 \pm 0.01 \\
\quad(-0.02 \text { to } 0.01)\end{array}$ & $\begin{array}{l}0.008 \pm 0.01 \\
\quad(-0.009 \text { to } 0.02)\end{array}$ \\
\hline
\end{tabular}

${ }^{1} 95 \%$ CI in parentheses.

FPL72 (Table 4). Increases in $\mathrm{R}^{2}$ adj for second-degree models of PL72 were $6.73,4.09,2.94$, and $1.27 \%$ for DAI, UDD, FUA, and RUW, respectively. Increases in $\mathrm{R}^{2}$ adj for second-degree models of FPL72 were 2.51, 2.22, and 1.24 for FUA, SUS, and DAI, respectively. According to the sign of the linear and quadratic regression coefficients, only DAI, UDD, and RUW showed intermediate maximums for either PL72 and FPL72 (Figures 1, 2, and 3), whereas the maximum for PL72 and FPL72 was observed when FUA (Figure 4) or SUS (Figure 5) values were extreme (minimum or maximum). Generally, departures from linearity were greater for PL72 compared with FPL72. In most cases, the form of the nonlinear relationship between the type trait and PL72, is similar to that for FPL72.

\section{DISCUSSION}

Mean scores for most type traits obtained in our study were within the range obtained by other authors in Alpine (Mellado et al., 2008; Valencia-Posadas et al., 2010) and Saanen (Mellado et al., 2008) and for all breeds studied (Luo et al., 1997; ADGA, 2012).

\section{Genetic Parameters}

The decision to conduct the analysis using the information for all breeds together was made to increase the sample size and have greater accuracy in the estimation of genetic parameters. We believe this was a logical way to proceed assuming we are looking at results of biological relationships that are relatively constant across breeds. Additionally, genetic parameters for type traits estimated separately for Alpine and Saanen goats did not differ substantially (Manfredi et al., 2001).

Although the genetic evaluation of productive life in goats is of great economic importance, it is not a commonly performed practice. This may be due in part to the fact that genetic parameters of productive life in goats are not yet well known. The heritability estimated in this work $\left(\mathrm{h}^{2}=0.19\right)$ was higher than estimates in cows $\left(h^{2}=0.08\right)$, using a definition of productive life very similar to that employed in our study (VanRaden and Klaaskate, 1993), stayability in goats (0.13; Torrero, 2010), or productive life in other species $\left(\mathrm{h}^{2}=0\right.$ to 0.16$)$, such as rabbits (Piles et al., 2006), swine (de Sevilla et al., 2008), and sheep (Riggio et al., 
Table 4. Nonlinear additive genetic relationships between productive life, functional productive life, and type traits in goats

\begin{tabular}{|c|c|c|c|c|c|c|c|}
\hline \multirow[b]{2}{*}{ Trait } & \multirow[b]{2}{*}{ Abbreviation } & \multicolumn{3}{|c|}{ Productive life at $72 \mathrm{mo}$ (PL72) } & \multicolumn{3}{|c|}{$\begin{array}{l}\text { Functional productive life } \\
\text { at } 72 \text { mo (FPL72) }\end{array}$} \\
\hline & & $\underset{(\%)}{\operatorname{Dif} \mathrm{R}^{2} \mathrm{adj}^{1}}$ & $\begin{array}{l}P \text {-value } \\
\text { linear }\end{array}$ & $\begin{array}{l}P \text {-value } \\
\text { quadratic }\end{array}$ & $\begin{array}{l}\operatorname{Dif} \mathrm{R}^{2} \mathrm{adj}^{1} \\
(\%)\end{array}$ & $\begin{array}{c}P \text {-value } \\
\text { linear }\end{array}$ & $\begin{array}{l}P \text {-value } \\
\text { quadratic }\end{array}$ \\
\hline Final score & $\mathrm{SCO}$ & 0.38 & $<0.0001$ & $<0.0001$ & 0.00 & 0.29 & 0.23 \\
\hline Stature & STA & 0.17 & $<0.001$ & $<0.001$ & 0.04 & 0.11 & 0.03 \\
\hline Strength & STR & 0.89 & $<0.0001$ & $<0.0001$ & 0.00 & 0.13 & 0.39 \\
\hline Rear legs (side view) & REL & 0.74 & $<0.0001$ & $<0.0001$ & 0.00 & 0.21 & 0.16 \\
\hline Rump angle & RUA & 0.06 & $<0.0001$ & 0.01 & 0.13 & $<0.0001$ & $<0.001$ \\
\hline Rump width & RUW & 1.27 & $<0.0001$ & $<0.0001$ & 0.26 & $<0.001$ & $<0.0001$ \\
\hline Fore udder attachment & FUA & 2.94 & $<0.0001$ & $<0.0001$ & 2.51 & $<0.0001$ & $<0.0001$ \\
\hline Rear udder height & RUH & 0.09 & 0.11 & $<0.01$ & 0.21 & $<0.001$ & $<0.001$ \\
\hline Rear udder arch & RUC & 0.00 & $<0.0001$ & 0.36 & 0.56 & $<0.05$ & $<0.0001$ \\
\hline Udder depth & UDD & 4.09 & $<0.0001$ & $<0.0001$ & 0.46 & $<0.0001$ & $<0.0001$ \\
\hline
\end{tabular}

${ }^{1}$ Difference in the adjusted coefficient of variation $\left(R^{2}\right.$ adj) between second degree and first degree regression models of breeding values.

2009). This suggests greater genetic variation for PL72 in dairy goats than in other species, thus the response to selection may be greater.

The estimated heritability of FPL72 (0.14) was somewhat less than that estimated for PL72 (0.19) due to the inclusion of covariates MIY, FAY, PRY, and SCO in the estimation model; however, this result suggests that, even when correcting for voluntary culling, significant opportunities exist for genetic improvement through selection programs with less influence of confounding effects of voluntary culling. The heritability estimate for FPL72 was greater than that estimated for functional productive life (FPL) in sheep (0.11; Riggio et al., 2009), at the upper limit of the range of FPL estimates in dairy cows (0.02 to 0.14; Samoré et al., 2010), and lower than estimates for FPL in swine (0.17; Serenius and Stalder, 2004).

Heritability estimates for REL (0.20) and FUA (0.25) were very similar to those obtained by Luo et al. (1997) and Wiggans and Hubbard (2001; 0.21 and 0.25 for REL and FUA, respectively) in US goats from the same breeds as those studied here. However, estimates

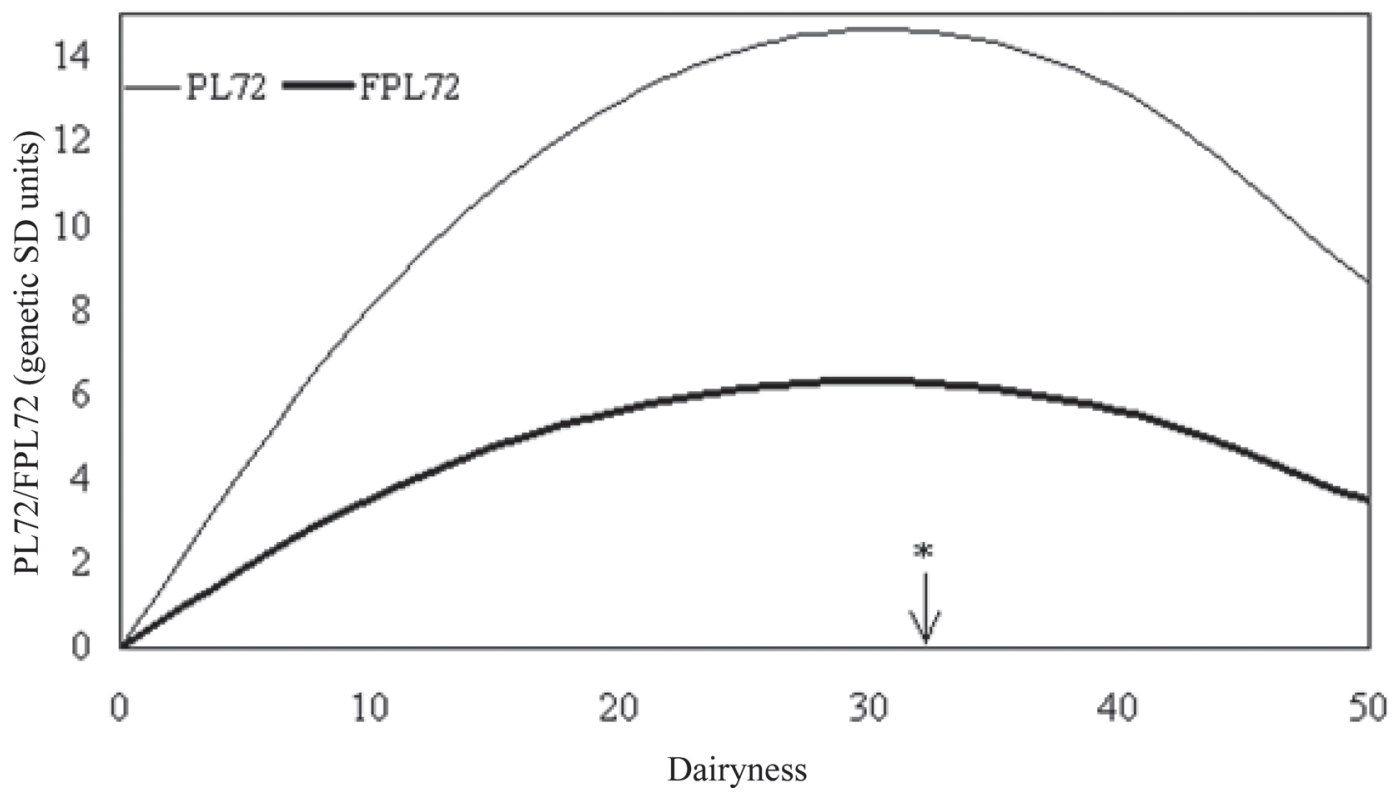

Figure 1. Second-degree polynomial regression models of predicted breeding values for productive life (PL72) or functional productive life (FPL72) according to dairyness score. ${ }^{*}$ Mean $=32.83$. 


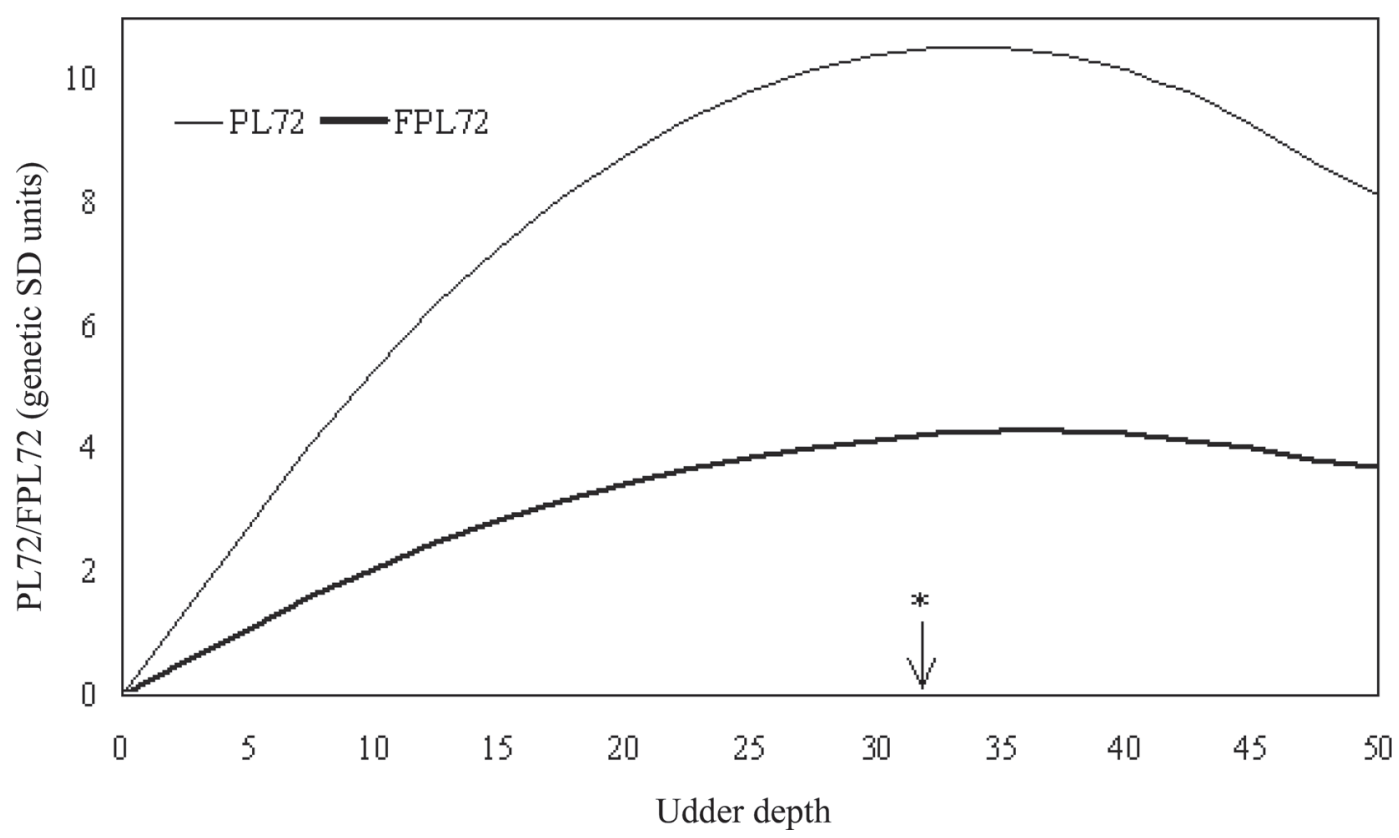

Figure 2. Second-degree polynomial regression models of predicted breeding values for productive life (PL72) or functional productive life (FPL72) according to udder depth score. ${ }^{*}$ Mean $=31.45$.

for STA (0.20), STR (0.14), DAI (0.07), TED (0.28), RUA (0.15), RUW (0.13), RUH (0.18), UDD (0.21), SUS (0.21) and TPS (0.32) were lower than the values from Luo et al. (1997) and Wiggans and Hubbard $(2001 ; 0.52,0.29,0.24,0.36,0.34,0.27,0.25,0.25,0.33$ and 0.36 for STA, STR, DAI, TED, RUA, RUW, RUH, UDD, SUS, and TPS respectively).

Heritability estimates obtained in our study for REL were higher than those obtained in Texel sheep (0.14; Janssens and Vandepitte, 2004), but heritabil-

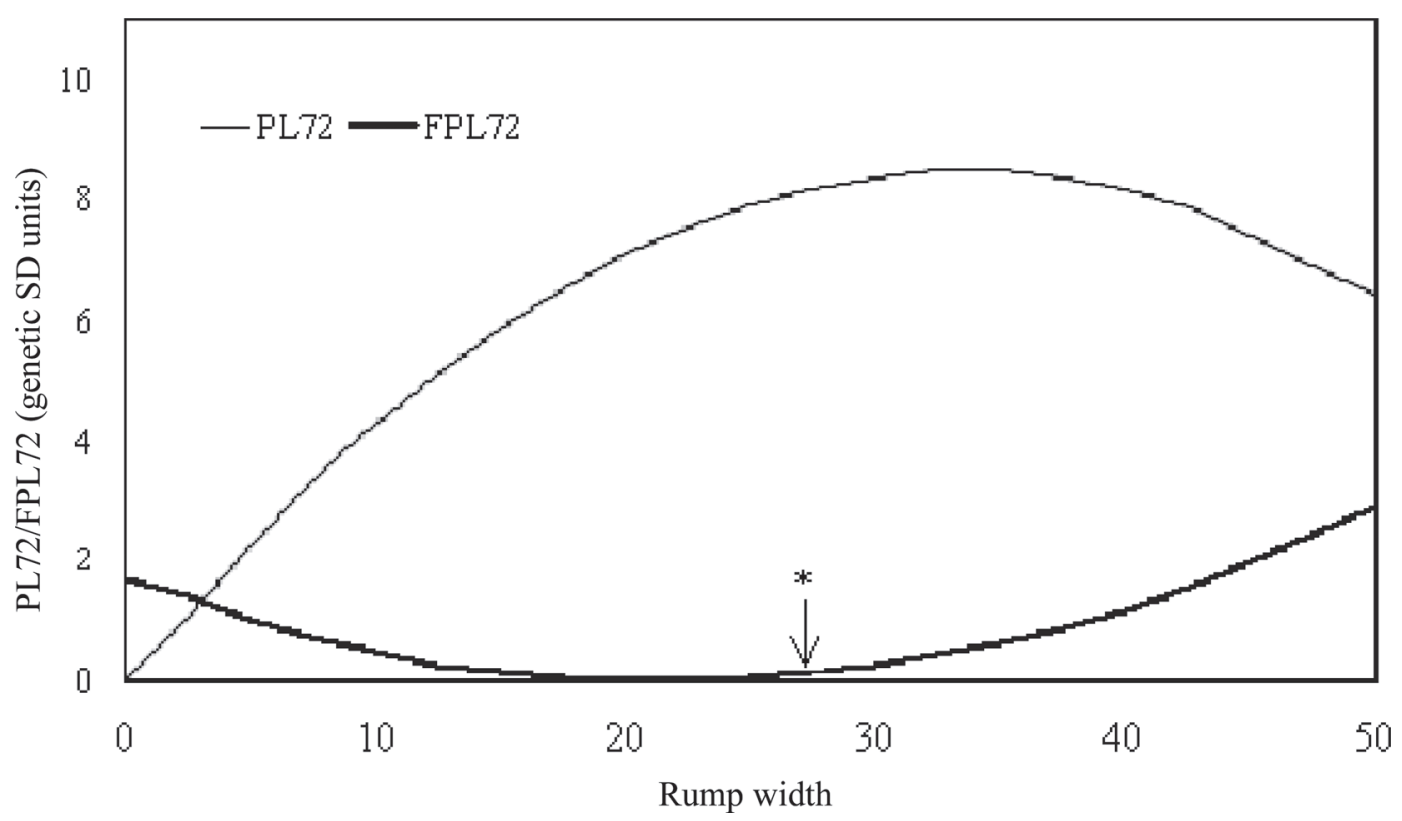

Figure 3. Second-degree polynomial regression models of predicted breeding values for productive life (PL72) or functional productive life (FPL72) according to rump width score. ${ }^{*}$ Mean $=27.01$. 


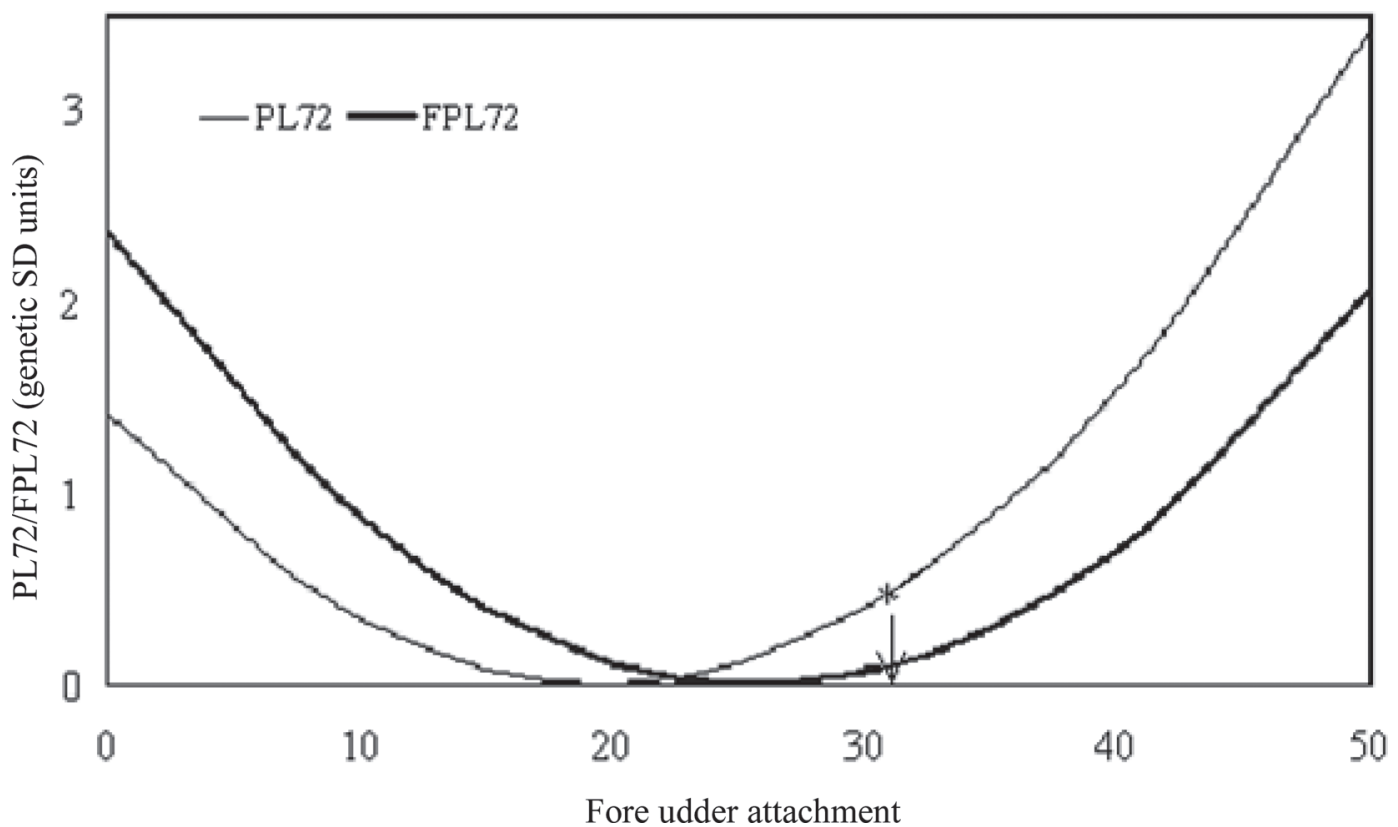

Figure 4. Second-degree polynomial regression models of predicted breeding values for productive life (PL72) or functional productive life (FPL72) according to fore udder attachment score. ${ }^{*}$ Mean $=31.57$.

ity estimates for FUA, TPS, and UDD were similar to that obtained in Laxta sheep $(0.26,0.40$, and 0.26 , respectively; Legarra and Ugarte, 2005) and dairy goats (0.25-0.26, 0.32, and 0.23, respectively; Manfredi et al., 2001; Rupp et al., 2011; McLaren et al., 2016). Interestingly, heritabilities of about 0.5 were reported for some type traits in goats when traits were measured rather than being subjectively scored (Manfredi et al., 2001; Rupp et al., 2011). Moreover, estimates of heritabilities of scored traits in goats can be high $(>0.5)$ when SNP are used to build a genomic relationship matrix (Carillier et al., 2014). In cows, different estimates of

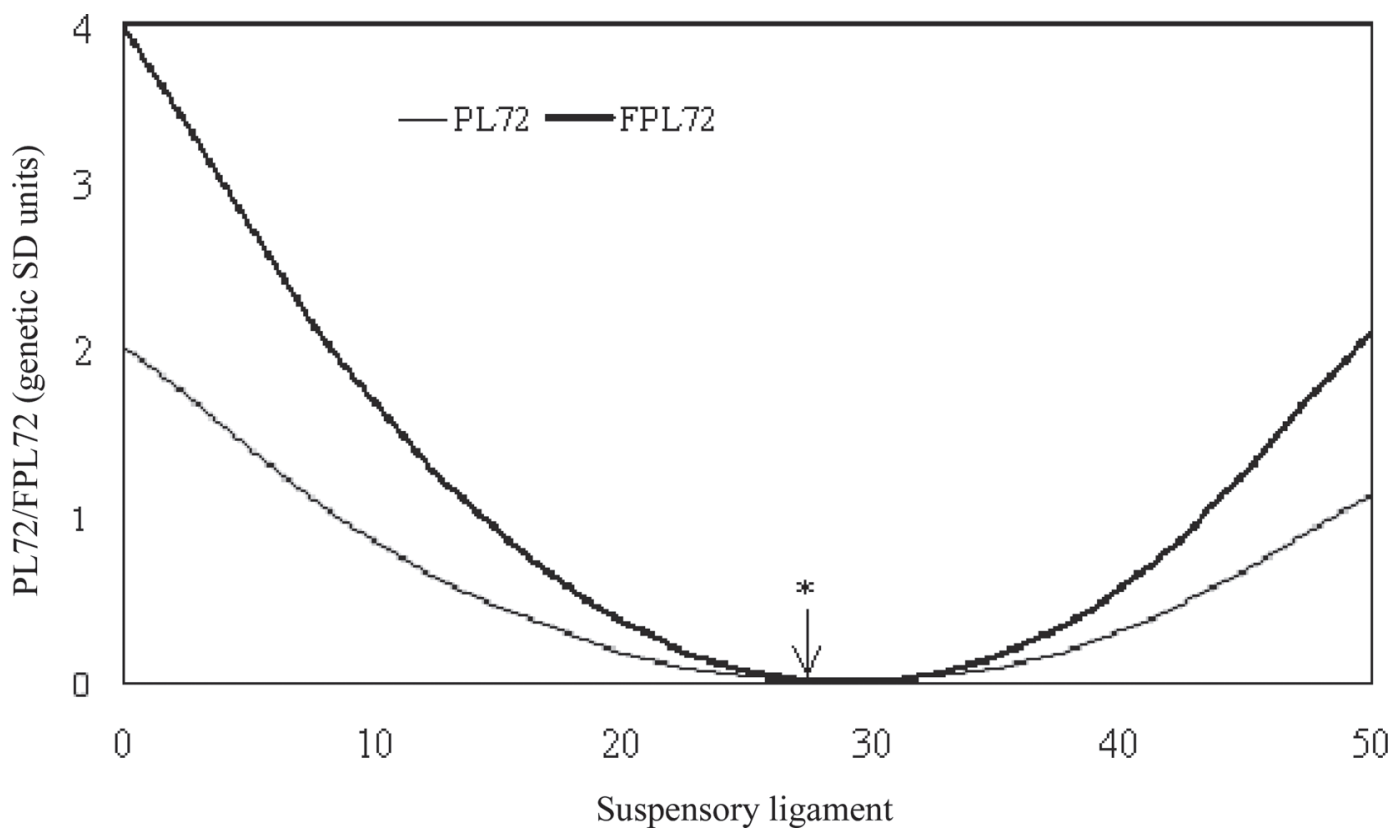

Figure 5. Second-degree polynomial regression models of predicted breeding values for productive life (PL72) or functional productive life (FPL72) according to suspensory ligament score. ${ }^{*}$ Mean $=27.07$. 
heritability exist (e.g., Valencia et al., 2008) for each trait depending on the breed, displaying a range of values for type traits of 0.04 to 0.54 .

Heritability estimates for type traits were from 0.07 to 0.32 , and most were within the range of heritability estimates previously obtained in goats (Luo et al., 1997; Wiggans and Hubbard, 2001), sheep (Janssens and Vandepitte, 2004; Legarra and Ugarte, 2005) and cows (Mark, 2004; Wiggans et al., 2004; Forabosco, 2005). The lowest heritability estimate was for DAI (0.07) and the highest for TPS (0.32). Heritability estimates for type traits were generally moderate, allowing genetic advances by selection to be obtained that coincide with that found by Luo et al. (1997).

\section{Genetic and Phenotypic Correlations}

Studies conducted in Holstein (Vollema and Groen, 1997; Tsuruta et al., 2005, Valencia et al., 2008) and Guernsey (Harris et al., 1992) cows, in which longevity was defined as stayability at 48 mo, obtained higher $\mathrm{r}_{\mathrm{g}}$ than those estimated in our study between PL72 and REL (0.01 vs. 0.12; Harris et al., 1992), UDD (0.17 vs. 0.38 and 0.52 ; Tsuruta et al., 2005; Valencia et al., 2008 ), or SUS (0.04 vs. 0.13 and 0.33 ; Vollema and Groen, 1997; Valencia et al., 2008). Upon comparing the $r_{g}$ when the longevity in cows was defined as the total months in production to a given age (Tsuruta et al., 2005), months of life (Forabosco, 2005), or stayability (Harris et al., 1992; Vollema and Groen, 1997), the $\mathrm{r}_{\mathrm{g}}$ estimated in the current study between SCO (0.52), STA (0.21), RUW (0.29), FUA (0.34), RUH (0.19), RUC (0.17), UDD (0.17), or TPS (0.06) and PL72 were higher than those estimated in Holstein $(0.13,-0.12$, 0.27, 0.10, 0.02, and 0.03 for SCO, STA, FUA, RUC, UDD, and TPS, respectively; Vollema and Groen, 1997; Tsuruta et al., 2005), Guernsey (0.08 and 0.07 for RUH and UDD, respectively; Harris et al., 1992) and Italian Chianina cows (0.06 and 0.03 for SCO and STA, respectively; Forabosco, 2005). In turn, the estimated $r_{g}$ between SCO (0.51; Valencia et al., 2008), REL ( -0.01 ; Vollema and Groen, 1997), RUA (0.03; Tsuruta et al., 2005), or FUA (0.30; Harris et al., 1992), and longevity in Holstein (Tsuruta et al., 2005) and Guernsey (Harris et al., 1992) cows or stayability in cows from the Holstein breed (Valencia et al., 2008), were similar to those estimated in our study $(0.52,0.01,-0.06$, and 0.34 , and, for SCO, REL, RUA, and FUA, respectively).

With regard to FPL72, the $\mathrm{r}_{\mathrm{g}}$ between FPL72 and STA, STR, REL, and RUA $(0.16,-0.10,0.09$, and -0.04 , respectively) were lower than the $r_{g}$ estimated in Guernsey cows $(-0.69,-0.73,0.16$, and -0.40 , respectively; Harris et al., 1992), as well as between FPL72 and SUS obtained in Holstein cows (0.02 vs. 0.12; Vollema and Groen, 1997). Unlike that observed in Guernsey cows, the $\mathrm{r}_{\mathrm{g}}$ between FPL72 and REL estimated in our study (0.09) was higher than that estimated in Holstein cows (-0.01; Vollema and Groen, 1997), as well as the $\mathrm{r}_{\mathrm{g}}$ between FPL72 and UDD obtained in Holstein (0.07; Vollema and Groen, 1997) and Guernsey cows (0.04; Harris et al., 1992). Likewise, the $r_{g}$ between FPL72 and RUH was greater than that estimated in Guernsey cows (0.09 vs. 0.01; Harris et al., 1992). Conversely, the $r_{g}$ between FPL72 and FUA was similar to that estimated in Guernsey cows (0.34 vs. 0.35; Harris et al., 1992), as well as the $\mathrm{r}_{\mathrm{g}}$ between FPL72 and TPS estimated in Holstein (0.12 vs. 0.09; Vollema and Groen, 1997) and Guernsey cows (0.12 vs. 0.11; Harris et al., 1992).

The $r_{\mathrm{g}}$ between udder traits (TED, FUA, RUH, RUC, UDD, SUS, and TPS) and PL72 ( -0.04 to 0.34$)$, with the exception of $r_{g}$ between PL72 and FUA (0.34), were lower than the range of values obtained by Tsuruta et al. (2004) between these traits and productive life in Holstein cows ( 0.26 to 0.38 ) using the total months in production up to 84 mo as a measure of productive life. In contrast to that found in sheep by Mekkawy et al. (2009), in the current study most of the estimated $r_{g}$ were different than zero, suggesting that, as in studies conducted on cows (e.g., Tsuruta et al., 2005), some type traits have a significant relationship with longevity. In our study, the type traits with the greatest $r_{\mathrm{g}}$ with PL72 and FPL72 were SCO, UDD (only for FPL72), and FUA. Valencia et al. (2008) found that the SCO, as well as TPS and UDD, were the most important traits to predict the stayability at 48 mo in cows.

The $r_{p}$ obtained in our study between PL72 and RUH $(0.11 \pm 0.01)$ and RUA $(-0.07 \pm 0.01)$ were higher than those obtained in Guernsey (Harris et al., 1992) and Holstein (Vacek et al., 2006) cows for RUH (0.06 to 0.08; Harris et al., 1992; Vacek et al., 2006) and RUA ( -0.04 to -0.06 ; Harris et al., 1992; Vacek et al., 2006). However, REL $(0.01 \pm 0.01)$, UDD $(-0.06 \pm 0.01)$, STR $(-0.01 \pm 0.01)$, and STA $(-0.02 \pm 0.01)$ were similar to those obtained in the same cows populations for RUH (0.06 to 0.08; Harris et al., 1992; Vacek et al., 2006), RUA ( -0.04 to -0.06 ; Harris et al., 1992; Vacek et al., 2006), REL (0.01; Vacek et al., 2006), UDD $(-0.05$; Vacek et al., 2006), STR $(-0.03$; Harris et al., 1992), and STA (-0.05; Harris et al., 1992).

The $r_{p}$ between PL72 and STA (-0.02), SUS (-0.02), and TPS $(-0.004)$ were lower than those obtained between longevity (Vacek et al., 2006) or stayability at 48 mo (Valencia et al., 2008) and STA (0.08; Vacek et al., 2006; Valencia et al., 2008), SUS (0.06; Valencia et al., 2008), and TPS (0.04; Vacek et al., 2006) in Holstein cows. The $r_{p}$ between PL72 and RUW (0.13), FUA (0.14), UDD (-0.06), SCO (0.25), and REL (0.01) were greater than the $r_{p}$ estimated in Holstein cows for 
RUW (0.07 to 0.10; Vacek et al., 2006; Valencia et al., 2008), FUA (0.02 to 0.09; Vacek et al., 2006; Valencia et al., 2008; Sawa et al., 2013), UDD ( -0.02 to -0.03 ; Vacek et al., 2006; Valencia et al., 2008), SCO (0.10 to 0.22; Valencia et al., 2008; Sawa et al., 2013), and REL (-0.07; Vacek et al., 2006).

In regard to FPL72, the $r_{p}$ estimated in our study were similar to those obtained in Holstein cows between functional longevity and TPS (0.01; Harris et al., 1992), RUA (-0.04; Harris et al., 1992), REL (-0.01; Harris et al., 1992), and STR (-0.03; Harris et al., 1992). These estimates were lower than those between FPL and UDD (0.03; Harris et al., 1992), STA (-0.06; Harris et al., 1992), and TPS (0.02; Harris et al., 1992), and greater in the case of the $r_{p}$ between FPL and RUH (0.04; Harris et al., 1992) as well as FUA (0.03; Harris et al., 1992) and STA.

The highest $r_{p}$ with PL72 and FPL72 were those obtained for SCO $(0.25 \pm 0.01$ and $0.22 \pm 0.01$, respectively), RUW $(0.13 \pm 0.01$ and $0.09 \pm 0.01$, respectively), FUA (0.14 \pm 0.01 and $0.13 \pm 0.01$, respectively), and RUH $(0.11 \pm 0.01$ and $0.09 \pm 0.01$, respectively). This coincides with that observed in Holstein (Berry et al., 2005, Vacek et al., 2006; Sawa et al., 2013) and Jersey cows (Berry et al., 2005), where cows with the lowest value in final score, fore udder attachment, and rear udder height are more likely to be culled, having a major influence on longevity and functional longevity.

In many studies conducted in cows we found similarities with the results obtained in the current study, confirming that SCO is, by far, the trait most genetically and phenotypically associated with longevity (Sewalem et al., 2004; Tsuruta et al., 2005), thereby making it an efficient predictor of longevity. This could be due to the fact that the value assigned to SCO could be an indication of the general state of health of the animal. Although SCO is the most important trait at the time of the decision to dispose of an animal, udder traits must also be taken into consideration at the time of selection, as they have an important influence on culling decisions, probably due to their influence on susceptibility to mastitis and other infectious diseases (Caraviello et al., 2003; Sewalem et al., 2004; Samoré et al., 2010).

Although we can say that the longevity is a trait of great economic importance for all species, it is important to recall that each species has different criteria for culling (Nielsen et al., 2003) and type appraisal systems (Luo et al., 1997). Thus, the establishment of an efficient genetic improvement plan should be constructed considering the characteristics and purposes of each species.

Our results show that the use of type traits is a viable option for the indirect improvement of productive life in milk-producing goats, and may therefore be used as a tool for the establishment of genetic improvement schemes for productive life. Considering the traits with the highest $\mathrm{r}_{\mathrm{g}}$ for PL72 and FPL72 were SCO, FUA, RUW, and UDD (only with FPL72), the selection of animals with better values for these traits may be efficient in the indirect improvement of productive life in goats. In addition, a need exists to estimate appropriate economic weights for inclusion of type traits in a selection index for the genetic improvement of productive life in this species. The use of genomic selection may help in selecting goats for breeding objectives that incorporate functional traits more efficiently at an early age and a lower cost. The accuracy of methods that solely use phenotypes of the genotyped animals and ignore records of the nongenotyped part of the population could be expected to be lower with a small population size (Mucha et al., 2015). This was observed in studies conducted with actual data on genomic prediction in goats using single-step methodology (Carillier et al., 2013, 2014). The implementation of a genomic breeding program in goats is something that has not yet been done on a full scale, primarily due to the lack of financial capacity to develop it. Knowledge of relationships between type traits and longevity traits may help in the design of recording schemes for dairy goat reference populations, which may in turn increase the accuracy of both genomic and traditional breeding values prediction.

\section{Nonlinear Genetic Relationships}

We estimated nonlinear relationships between breeding values, which is different to other studies conducted in cows (e.g., Pérez-Cabal et al., 2006; Vacek et al., 2006; Zavadilová and Štípková, 2012) that used phenotypic relationships, because environmental associations may change the form of the association. Although statistical evidence exists for additive genetics nonlinear associations for many type traits with either PL72 or FPL72, the consequences of most departures from linearity are either small or of no use for changing the selection procedures based on index selection.

Whereas the methods of appraisal used to obtain type trait scores in dairy animals have been questioned due to the lack of objective measurement scales, the use of some of these traits as selection criteria may increase PL72 and FPL72 in dairy goats. Based on our results, increases of FPL72 can be obtained by selecting animals with intermediate values of DAI and UDD, as well as the (minimum or maximum) extreme values of FUA, RUW, and SUS.

The combination of many traits to achieve a specific goal is common in a breeding program. This objective may be achieved using selection index methodology; 
however, in this particular case, it was observed that some conformation traits have optimal intermediates to increase productive life and improve the economic value of goats, thus suggesting that selection index methodology may not be the most appropriate approach. In this case, using restricted selection index methodology (Kempthorne and Nordskog, 1959), whose main purpose is to maintain certain traits at a desired level (Hovenier et al., 1993), including those traits with an optimal intermediate, may increase productive life selection response. In any case, the best selection procedure will need to be determined calculating the consequences of a particular selection strategy within each generation, considering the average values of all traits considered.

\section{CONCLUSIONS}

Genetic improvement of type traits by selection is a viable option, as, in general, their heritability estimates allow for good response to selection. Final score, rump width, and fore udder attachment are highly correlated with productive life and functional productive life, as well udder depth in the case of functional productive life; thus, they may be used as selection criteria to indirectly increase productive life in dairy goats. Nonlinear relationships exist between many type traits and productive life. An indirect increase in longevity is possible by selecting goats with extreme scores for fore udder attachment and suspensory ligament. Dairyness and udder depth have optimal intermediates for functional productive life; thus the inclusion of these traits in a genetic improvement program must consider this information in selection programs for increasing productive life in dairy goats.

\section{ACKNOWLEDGMENTS}

The authors thank the American Dairy Goat Association for providing the data used in this study and for publication support.

\section{REFERENCES}

ADGA. 2012. American Dairy Goat Association Guide Book. American Dairy Goat Association. Spindale, NC.

Berry, D. P., B. L. Harris, A. M. Winkelman, and W. Montgomerie. 2005. Phenotypic associations between traits other than production and longevity in New Zealand dairy cattle. J. Dairy Sci. 88:2962-2974.

Caraviello, D. Z., K. A. Weigel, and D. Gianola. 2003. Analysis of the relationship between type traits, inbreeding, and functional survival in Jersey cattle using a Weibull proportional hazards model. J. Dairy Sci. 86:2984-2989.

Carillier, C., H. Larroque, I. Palhière, V. Clément, R. Rupp, and C. Robert-Granié. 2013. A first step toward genomic selection in the multi-breed French dairy goat population. J. Dairy Sci. 96:72947305 .
Carillier, C., H. Larroque, and C. Robert-Granié. 2014. Comparison of joint versus purebred genomic evaluation in the French multibreed dairy goat population. Genet. Sel. Evol. 46:67.

Castañeda-Bustos, V. J., H. H. Montaldo, G. Torres-Hernández, S. Pérez-Elizalde, M. Valencia-Posadas, O. Hernández-Mendo, and L. Shepard. 2014. Estimation of genetic parameters for productive life, reproduction, and milk-production traits in US dairy goats. J. Dairy Sci. 97:2462-2473.

Chauhan, V. P. S. 1987. Dairy sire evaluation fitting some of the herd year-season effects as random. Livest. Prod. Sci. 16:117-130.

Dekkers, J. C. M., and J. P. Gibson. 1998. Applying breeding objectives to dairy cattle improvement. J. Dairy Sci. 81:19-35.

Draper, N. R., and H. Smith. 2014. Applied Regression Analysis. John Wiley \& Sons, Hoboken, NJ.

de Sevilla, X. F., E. Fàbrega, J. Tibau, and J. Casellas. 2008. Effect of leg conformation on survivability of Duroc, Landrace, and Large White sows. J. Anim. Sci. 86:2392-2400.

du Toit, J., J. B. van Wyk, and A. Maiwashe. 2009. Genetic parameter estimates for functional herd life for the South African Jersey breed using a multiple trait linear model. S. Afr. J. Anim. Sci. 39:40-44.

Fletcher, T. D. 2010. Psychometric: Applied Psychometric Theory. $\mathrm{R}$ package version 2.2. Accessed Oct. 25, 2014. http://CRAN.Rproject.org $/$ package $=$ psychometric.

Forabosco, F. 2005. Breeding for longevity in Italian Chianina cattle. $\mathrm{PhD}$ thesis. Department of Animal Science, Wageningen University, Wageningen, the Netherlands.

Foster, W. W., A. E. Freeman, P. J. Berger, and A. Kuck. 1989. Association of type traits scored linearly with production and herdlife of Holsteins. J. Dairy Sci. 72:2651-2664.

Fuerst-Waltl, B., J. Sölkner, A. Essl, I. Hoeschele, and C. Fuerst. 1998. Non-linearity in the genetic relationship between milk yield and type traits in Holstein cattle. Livest. Prod. Sci. 57:41-47.

Gilmour, A. R., B. J. Gogel, B. R. Cullis, and R. Thompson. 2009 ASReml User Guide Release 3.0. VSN International Ltd., Hemel Hempstead, UK.

Harris, B. L., A. E. Freeman, and E. Metzger. 1992. Analysis of herd life in Guernsey dairy cattle. J. Dairy Sci. 75:2008-2016.

Hovenier, R., E. W. Brascamp, E. Kanis, J. H. J. Van der Werf, and A. P. A. M. Wassenberg. 1993. Economic values of optimum traits: the example of meat quality in pigs. J. Anim. Sci. 71:1429-1433.

Janssens, S., and W. Vandepitte. 2004. Genetic parameters for body measurements and linear type traits in Belgian Bleu du Maine, Suffolk and Texel sheep. Small Rumin. Res. 54:13-24.

Jensen, J., I. R. Korsgaard, H. J. Neerhof, A. Vollema, P. Madsen, and V. Ducrocq. 1999. Genetic variation in functional longevity and its relation to mastitis resistance in Danish Holstein. Interbull Bull. 21:161-165.

Kempthorne, O., and A. W. Nordskog. 1959. Restricted selection indices. Biometrics 15:10.

Kinghorn, B., and S. Kinghorn. 2009. Pedigree Viewer 6.3. Accessed Mar. 14, 2012. http://metz.une. edu.au/ bkinghor/pedigree.htm.

Larroque, H., and V. Ducrocq. 2001. Relationships between type and longevity in the Holstein breed. Genet. Sel. Evol. 33:39-59.

Legarra, A., and E. Ugarte. 2005. Genetic parameters of udder traits, somatic cell score, and milk yield in Latxa sheep. J. Dairy Sci. 88:2238-2245.

Luo, M. F., G. R. Wiggans, and S. M. Hubbard. 1997. Variance component estimation and multitrait genetic evaluation for type traits of dairy goats. J. Dairy Sci. 80:594-600.

Manfredi, E., A. Piacère, P. Lahaye, and V. Ducrocq. 2001. Genetic parameters of type appraisal in Saanen and Alpine goats. Livest. Prod. Sci. 70:183-189.

Mark, T. 2004. Applied genetic evaluations for production and functional traits in dairy cattle. J. Dairy Sci. 87:2641-2652.

McLaren, A., S. Mucha, R. Mrode, M. Coffey, and J. Conington. 2016. Genetic parameters of linear conformation type traits and their relationship with milk yield throughout lactation in mixed-breed dairy goats. J. Dairy Sci. 99:5516-5525.

Mekkawy, W., R. Roehe, R. M. Lewis, M. H. Davies, L. Bunger, G. Simm, and W. Haresign. 2009. Genetic relationship between lon- 
gevity and objectively or subjectively assessed performance traits in sheep using linear censored models. J. Anim. Sci. 87:3482-3489.

Mellado, M., J. Mellado, M. Valencia, and W. Pittroff. 2008. The relationship between linear type traits and fertility traits in highyielding dairy goats. Reprod. Domest. Anim. 43:599-605.

Mrode, R. A. 2005. Linear Models for the Prediction of Animal Breeding values. 2nd ed. CAB International, Wallingford, UK.

Mucha, S., R. Mrode, I. MacLaren-Lee, M. Coffey, and J. Conington. 2015. Estimation of genomic breeding values for milk yield in UK dairy goats. J. Dairy Sci. 98:8201-8208.

Nielsen, U. S., O. M. Pedersen, and M. Toivonen. 2003. Time dependent effects as source of bias in estimating breeding values for longevity and fertility traits. Interbull Bull. 30:29-34.

Pérez-Cabal, M. A., C. García, O. González-Recio, and R. Alenda. 2006. Genetic and phenotypic relationships among locomotion type traits, profit, production, longevity, and fertility in Spanish dairy cows. J. Dairy Sci. 89:1776-1783.

Pérez-Razo, M., F. Sánchez, G. Torres-Hernández, C. Becerril-Pérez, J. Gallegos-Sánchez, F. González-Cosío, and C. Meza-Herrera. 2004. Risk factors associated with dairy goats stayability. Livest. Prod. Sci. 89:139-146.

Piles, M., H. Garreau, O. Rafel, C. Larzul, J. Ramon, and V. Ducrocq 2006. Survival analysis in two lines of rabbits selected for reproductive traits. J. Anim. Sci. 84:1658-1665.

Riggio, V., D. O. Maizon, B. Portolano, H. Bovenhuis, and J. A. M. van Arendonk. 2009. Effect of somatic cell count level on functional longevity in Valle del Belice dairy sheep assessed using survival analysis. J. Dairy Sci. 92:6160-6166.

Rogers, G. W., G. Banos, U. Sander Nielsen, and J. Philipsson. 1998 Genetic correlations among somatic cell scores, productive life, and type traits from the United States and udder health measures from Denmark and Sweden. J. Dairy Sci. 81:1445-1453.

Rupp, R., V. Clément, A. Piacere, C. Robert-Granié, and E. Manfredi. 2011. Genetic parameters for milk somatic cell score and relationship with production and udder type traits in dairy Alpine and Saanen primiparous goats. J. Dairy Sci. 94:3629-3634.

Samoré, A. B., R. Rizzi, A. Rossoni, and A. Bagnato. 2010. Genetic parameters for functional longevity, type traits, somatic cell scores, milk flow and production in the Italian Brown Swiss. Ital. J. Anim. Sci. 9(e28):145-152.

Sawa, A., M. Bogucki, S. Krwhel-Czopek, and W. Neja. 2013. Relationship between conformation traits and lifetime production efficiency of cows. ISRN Vet. Sci. 2013:124690.

Schaeffer, L. R. 2004. Estimation of Variance Components in Animal Breeding. Lecture Note, Iowa State University. Accessed Sep. 15 2014. http://www.aps.uoguelph.ca/ lrs/ABModels/NOTES/ VCNotes.pdf.

Schaeffer, L. R. 2009. Contemporary Groups Are Always Random. Accessed Jul. 15, 2016. http://www.aps.uoguelph.ca/ lrs/LRSsite/ ranfix.pdf.

Searle, S. R. 1987. Linear Models for Unbalanced Data. J. Wiley \& Sons, New York, NY.

Serenius, T., and K. J. Stalder. 2004. Genetics of length of productive life and lifetime prolificacy in the Finnish Landrace and Large White pig populations. J. Anim. Sci. 82:3111-3117.

Sewalem, A., G. J. Kistemaker, F. Miglior, and B. J. Van Doormaal 2004. Analysis of the relationship between type traits and functional survival in Canadian Holstein using a Weibull Proportional Hazard Model. J. Dairy Sci. 87:3938-3946.
Sewalem, A., F. Miglior, G. J. Kistemaker, P. Sullivan, G. Huapaya, and B. J. Van Doormaal. 2007. Short communication: Modification of genetic evaluation of herd life from a three-trait to a fivetrait model in Canadian dairy cattle. J. Dairy Sci. 90:2025-2028.

Sewalem, A., F. Miglior, G. J. Kistemaker, P. Sullivan, and B. J. Van Doormaal. 2008. Relationship Between reproduction traits and functional longevity in Canadian dairy cattle. J. Dairy Sci. 91:1660-1668.

Shepard, L. 2009. Performance Programs-Your "Genetic Toolbox". Pages 1-2 in Proceedings of the 24th Annual Goat Field Day, Langston University. National Institute of Food and Agriculture, USDA, Washington, DC.

Tarrés, J., J. P. Bidanel, A. Hofer, and V. Ducrocq. 2006. Analysis of longevity and exterior traits on Large White sows in Switzerland. J. Anim. Sci. 84:2914-2924.

Torrero, G. Y. 2010. Estimación de covarianzas para características de longevidad y producción en cabras. Tesis de Maestría. Universidad de Guanajuato, Irapuato, México.

Tsuruta, S., I. Misztal, and T. J. Lawlor. 2004. Genetic correlations among production, body size, udder, and productive life traits over time in Holsteins. J. Dairy Sci. 87:1457-1468.

Tsuruta, S., I. Misztal, and T. J. Lawlor. 2005. Changing definition of productive life in US Holsteins: Effect on genetic correlations. J. Dairy Sci. 88:1156-1165.

Vacek, M., M. Štipkova, E. Němcova, and J. Bouška. 2006. Relationships between conformation traits and longevity of Holstein cows in the Czech Republic. Czech J. Anim. Sci. 51:327-333.

Valencia, P. M., V. H. H. Montaldo, and L. F de J. Ruíz. 2008. Parámetros genéticos para características de conformación, habilidad de permanencia y producción de leche en ganado Holstein en México. Técnica Pecuaria en México 46:235-248.

Valencia-Posadas, M., Y. Torrero-Garza, C. V. Vicencio-Reyes, L. Shepard, and H. H. Montaldo. 2010. Relaciones fenotípicas entre características de conformación con la habilidad de permanencia a los 36 meses en cabras Alpinas. Acta Universitaria 20:40-44.

Van Bebber, J., N. Reinsch, W. Junge, and E. Kalm. 1997. Accounting for herd, year and season effects in genetic evaluations of dairy cattle: A review. Livest. Prod. Sci. 51:191-203.

VanRaden, P. M., and E. J. H. Klaaskate. 1993. Genetic evaluation of length of productive life including predicted longevity of live cows. J. Dairy Sci. 76:2758-2764.

Vollema, A. R., and A. B. F. Groen. 1997. Genetic correlations between longevity and conformation traits in an upgrading dairy cattle population. J. Dairy Sci. 80:3006-3014

Wiggans, G. R. 2006. USDA Genetic Evaluation Program for Dairy Goats. Accessed May 17, 2014. http://aipl.arsusda.gov.

Wiggans, G. R., and F. N. Dickinson. 1985. Standardization of NCDHIP dairy cattle lactation records. Natl. Coop. DHI Pmg. Handbook, Fact Sheet G-2, Natl. Coop. DHIA, Washington, DC.

Wiggans, G. R., N. Gengler, and J. R. Wright. 2004. Type trait (co) variance components for five dairy breeds. J. Dairy Sci. 87:23242330 .

Wiggans, G. R., and S. M. Hubbard. 2001. Genetic evaluation of yield and type traits of dairy goats in the United States. J. Dairy Sci. 84:E69-E73

Zavadilová, L., and M. Štípková. 2012. Genetic correlations between longevity and conformation traits in the Czech Holstein population. Czech J. Anim. Sci. 57:125-136. 